\title{
How to Improve the Employee Productivity of Banking System in India - a Theory of Accountability Based Analysis
}

\author{
P. S. Aithal ${ }^{1}$, Prasanna Kumar ${ }^{1}$, \& Mike Dillon ${ }^{2}$ \\ ${ }^{1}$ College of Business Management \& Commerce, Srinivas University, Mangalore, India. \\ E-mail: psaithal@gmail.com \\ ${ }^{2}$ Institute of Productivity, Grimsby, United Kingdom \\ E-mail: mike@instituteofproductivity.com
}

Type of the Paper: Research Paper.

Type of Review: Peer Reviewed.

Indexed in: OpenAIRE.

DOI: http://doi.org/10.5281/zenodo.1468380.

Google Scholar Citation: IJMTS

\section{How to Cite this Paper:}

Aithal, P. S., Kumar, Prasanna., \& Mike Dillon. (2018). How to Improve the Employee Productivity of Banking System in India - a Theory of Accountability Based Analysis. International Journal of Management, Technology, and Social Sciences (IJMTS), 3(2), 8799. DOI: http://doi.org/10.5281/zenodo.1468380.

International Journal of Management, Technology, and Social Sciences (IJMTS) A Refereed International Journal of Srinivas University, India.

(C) With Authors.

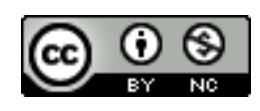

This work is licensed under a Creative Commons Attribution-Non Commercial 4.0 International License subject to proper citation to the publication source of the work.

Disclaimer: The scholarly papers as reviewed and published by the Srinivas Publications (S.P.), India are the views and opinions of their respective authors and are not the views or opinions of the SP. The SP disclaims of any harm or loss caused due to the published content to any party. 


\title{
How to Improve the Employee Productivity of Banking System in India - a Theory of Accountability Based Analysis
}

\author{
P. S. Aithal ${ }^{1}$, Prasanna Kumar ${ }^{1}$, \& Mike Dillon ${ }^{2}$ \\ ${ }^{1}$ College of Business Management \& Commerce, Srinivas University, Mangalore, India. \\ E-mail:psaithal@gmail.com \\ ${ }^{2}$ Institute of Productivity, Grimsby, United Kingdom \\ E-mail: mike@instituteofproductivity.com
}

\begin{abstract}
The recently developed theory called Theory of Accountability (Theory A) for organizations of $21^{\text {st }}$ century identifies the various factors which affect the organizational human resources performance. The essential components identified to improve the productivity of any organization based on the postulates of Theory A are (1) Planning, (2) Target setting, (3) Motivation, (4) Work Strategies, (5) Responsibility, (6) Role model, (7) Monitoring \& Guiding, and (8) Accountability. The objective of this paper is to apply the components of Theory A to Indian Banking system and to study how to improve the productivity of the banking system for economic progress in India. Accordingly we analysed the business model and the organizational strategy of Indian Banks in terms of their business objectives, service planning, target setting for the employees, employee motivational factors, working strategies to improve productivity, selfand mutual responsibilities among individual employees and in their teams, concept of role model in banking service innovation, continuous monitoring and guiding strategies, and finally accountability of each and every employee at different organizational levels. The applicability of Theory A on both private and public sector banks are discussed in general and suitable suggestions are proposed to the banking sector to improve productivity based on the postulates of Theory A.
\end{abstract}

Keywords: Theory of Accountability, Organizational performance theory of $21^{\text {st }}$ century, Productivity enhancement, Improved output performance.

\section{INTRODUCTION :}

Banking is a tertiary industrial sector with the objective of providing suitable services related to financial lending and financial transactions for registered customers. Banks are basically started to attract and collect deposits from the interested customers, by giving benefits to the depositors in the form of periodic interest and invest that money to lend in the form of various kinds of loans to collect periodic interest in addition to lent principal amount to make profit in addition of imposing service charges for various banking services related to money transactions. Banks can improve their profit by improving the quality of service to the customers. Banking system, in general, has undergone many changes during last few years due to the adoption of information communication and computation technology in various banking processes and changes further due to continuous changes in technology, as well as customers' demands for new kinds of services. The pressure on banks due to competition within the industry also made them to look into many related financial services and portfolios other than pure banking services. This includes expansion to insurance sector either individually or through collaboration. During the last many years, a lot of variations in banks performance is observed. To avoid the repetition of such incidents, organizations need to focustheir attention on examining and managing the organization building activities. This 
includes organizational values, employee information, employee performance, bank integrity, secured services, and transparency in the many processes. A major part of the failure of banking performance is attributed to human factors like employee performance in terms of long-term accountability along with many other factors [1-3].

A banking system consists of many branches interconnected into a system and the registered customers of any branch can avail offered services in any branch. Every customer can seek and avail designated service either online or physically entering to the branch of the bank. Based on networking of bank branches, a customer has provision for availing any service from any branches of the bank. Using the internet and wireless technology, a customer can avail banking services using electronic banking and mobile banking models. Even though such automation of banking services through online banking reduces the employee's touch points with the customers and hence a number of employees in a bank, including technical staff and essential employees are certainly required and in order to decrease the service cost, the primary solution is to improve the productivity.

To improve any present systems, it is normal practice that such systems have to be compared with a hypothetical, predicted system of that kind called "Ideal system" [4-6]. By comparing the properties/characteristics of a practical system with its ideal counterpart, one can find out the possible modifications in that device /system towards reaching the objective of realizing such an ideal system [7]. The ideal banking system model is developed and by considering various characteristics under 4 categories such as Input conditions, Systems requirements, Output conditions, and Environmental \& social conditions, and the possibility of realizing such systems is discussed [8]. In order to improve the present performance of the banks worldwide, one has to study the various factors which affect the banking services. Apart from, banking model used, technology adopted, and services provided, the bank employee productivity plays important role in deciding the banking industry performance.
The conventional model of the banking system can be improved in its performance without changing its objectives and functions using information communication and computation technology so that the speed, quality, accuracy, and convenience of banking services to its customers will improve to a great extent [9-10]. In this paper, we have discussed the productivity of banking system based on the performance of its employees at different organizational level using a recent theory on organizational performance called Theory of Accountability. Using the determinant components of theory A, we analysed the business model and the organizational strategy of Indian Banks in terms of their business objectives, service planning, target setting for the employees, employee motivational factors, working strategies to improve productivity, self-and mutual responsibilities among individual employees and in their groups, concept of role model in banking service innovation, continuous monitoring and guiding strategies, and finally accountability of each and every employees at different organizational levels.

\section{PRODUCTIVITY IN BANKING} SYSTEM:

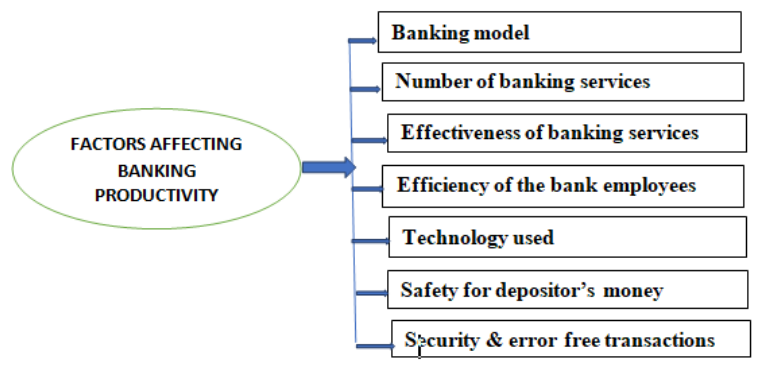

Fig. 1 : Factors affecting the Productivity in Bank System

It is well known that globally many banks are under performing due to poor quality of their services and hence profitability. This is true for Indian banks both of public sector and private sector [11-14]. Various factors are found to be affecting the quality of banks services include : (1) The type of banking model used, (2) The number of services, (3) Effectiveness of banking services, (4) Efficiency of the service providers (bank employees), (5) The technology used, (6) Safety for depositor's money, and (7) The 
security \& error free transactions. The details on each factor are discussed below :

\section{(1) Type of banking model used :}

There are numbers of strategic options open to banks. These strategic options in banking model depend on the scope of the banks' own activities as well as expected profitability. The traditional brick and mortar banking model and the infrastructure provider model are both asset intensive and have low profit margin and hence are unattractive. The open platform aggregator banking model, in fact,is the best option for a sustainable high margin apart from E-banking model presently popular in many countries. Since most of the banking operations are automated and integrated, e-banking model is highly productive.

(2) Number of banking services :

The banks are providing a number of services to their customers which includes financial and non-financial services. Some of them are Business loans, Checking accounts, Savings accounts. Debit and credit cards, Merchant services (credit card processing, reconciliation, and reporting, check collection), and Cash management (payroll services, deposit services, etc.). Each of these services contributes for productivity if properly managed.

(3) Effectiveness of banking services:

Effectiveness of banking services needs to be improved in the workplace. It may lead to retain the customers and increase the customer base. There's a cut throat competition between banks and effectiveness of services helps themto calm superior in service offerings.

(4) Efficiency of the bank employees:

There's a need of $100 \%$ commitment from the employees of the banks irrespectively of public and private banks. Efficiency and effectiveness of the employees' effect on productivity in the working environment. It leads to improving the relationship with customers.

\section{(5) Technology used:}

The information communication and computation technology drastically changed the view of banking services. New technologies are updating in daily services to attract many customers and give optimum service quality.

(6) Safety for depositor's money :
Once the money is deposited into the banks, it should be protected and available by $24 \times 7$. None of the hackers and crackers are able to steal the funds deposited in the name of the depositor. The financial services offered by banks legally bounded and transparency is mandatory. There are different options available to lenders to deposit the money into the bank.

\section{(7) Security \& error free transactions:}

It's an important point that Security \& error free transactions should be there in any commercial banks. It's a privilege to the banks that the customer's data and transactions are safe and secured. There should be a no chance of getting a loophole in loosing data of employees and customers.

Every banking institution aims to become a world-class service provider to compete effectively within the industry. The performance of the bank employees plays an important role in improving operational efficiency and effectiveness of the banking processes. This, in turn, improves the productivity of the banking system. Some of the issues discussed in various reviews [11-14] to improve the banking productivity includes (1) Aggressive sales target, (2) Benchmark for customer service, (3) Continuous training for employees, (4) Goal setting, tracking and performance review, (5) Checking honesty and integrity of employees, (6) Frequent motivation, (7) Optimum compensation and benefits, (8) Trained employees to use Digital Model effectively, etc.

\section{OBJECTIVE OF STUDY :}

The objective of this study is to investigate the effect of various determinant components of an organizational employee (HR) performance theory called Theory of Accountability (Theory A) on the productivity ofglobal banking sector in general, and Indian banking sector in specific. The interpretation is based on the analysis of the conceptual determinant components of Theory A applied at different organizational level of the banking industry for enhanced employees' performance by considering both public sector banking systems and private sector banking sectors in general. Finally, to develop some general suggestions to banking sector based on 
the essential determinant components of Theory A.

\section{THEORY OF ACCOUNTABILITY :}

The recently developed theory called Theory of Accountability (Theory A) for organizations of the $21^{\text {st }}$ century identifies the various factors which affect the organizational human resources performance. It emphasizes on the employee inspiration and accountability. Theory A, developed by Aithal P. S. and Suresh Kumar [15] overrides the existing propositions of organizational human behaviour and motivation by considering a new and extended set of propositions to improve the productivity based on human performance. Theory A provides better insights into the contemporary perspective of organizational performance based on controlling employee mindset in a systematic way. The quest for creativity, propels the employee to contribute to the organization by drawing positive energy from his innate potential and focussed to best performance models around him through his positive environment. Theory A supports every management of organizations to develop a strategy to enhance the output by making its employees to deliver targets as responsibility, commitment, and role model based stimulation coupled with accountability to enhance the efficiency.

The essential determinant components identified to improve the productivity of any organization based on the postulates of Theory A [15-22] are (1) Planning, (2) Target setting, (3) Motivation, (4) Work Strategies, (5) Responsibility, (6) Role model, (7) Monitoring \& Guiding, and (8) Accountability.The postulates of theory A connect the following factors of organizational performance [16] :

(1) Planning : As per Theory A, the vision, mission, and objectives of an organization should be clear on the organizational contribution towards development. Planning is the first determinant component of the theory A and finds a prominent role in transforming an organization by an optimized contribution from its employees. Theory A promotes employee planning in order to improve their contribution by understanding the organizational objectives. By jointly setting the objectives of the organization, an organization can encourage its employees to think and contribute innovatively. Theory A also suggests that the organization can develop its planning strategy as the blue ocean to become a monopoly in its business. The planning component of theory A also supports the involvement of employees in analysing the institutional strengths, weaknesses, opportunities, and challenges, either individually or jointly in order to transform the organization into a highly productive organization [17].

(2) Target setting : Target setting is the second determinant component of Theory $\mathrm{A}$ and is include setting the time bound target of individual and group of employees of the organization. Target can be set for the entire number of employees individually as activity target or jointly as output target. Time bound targets can be fixed for quarterly, half yearly, or annually based on institutional policy and should be communicated in time to every employee in the organization. Such a simulative environment creates challenges for the employees and makes them to redefine their individual and group goal. The strategy of target setting for individuals and groups in an organization according to theory A makes everybody to prepare and devote their effort towards better performance [18].

(3) Motivation : Motivation in Theory A is the third component and is helpful to the employees to discover their own potential through selfexploration. As per theory A, once the target for the optimum performance by the employees is set, the authorities of the organization should develop and implement policies to help the employees to meet the targets. Theory A identifies various motivational factors which support to identify weaknesses of employees, encouragement to perform at par with others, appreciation of individual contribution and performance, encouragement for collaborative works, developing task-based strategies for better performers etc [19].

(4) Work Strategies : Work strategy being the fourth component of Theory A is important for success. Work strategy promotes a time-frame plan for individuals and groups to fulfil their 
target. Thus, Theory A proposes teamwork through collaborative efforts with other people simultaneously as a multitasking model. Redefining the target based on its successive fulfilment is another enabling part of the work strategies [20].

(5) Responsibility : This is the major component of Theory A and contributes to both individual and organizational success. When the employees show their responsibility towards contributing towards the organizational objective, the productivity of the organization will enhance. It is argued that based on personality type, only a few people can take responsibility by themselves for organizational contribution. External stimulus is required for others to point out their responsibilities. Other components of Theory A like target setting, motivation, encouragement, continuous followup, or showcasing a role model in internal or external to the organization is also to stimulate the responsibility among the employees [15].

(6) Role model : Employees in every organization should realize that a given challenge through target setting is possible to achieve. Only achievable objectives should be set while target setting stage. By showcasing the role models either internal or external to the organization in a similar field, any organization can build confidence among the employees and prove that the set targets can be achievable. A role model can be any employee in the organization who outperform and contribute highest to the organization. Irrespective of age, gender, position and any kind of administrative responsibilities, role models can inspire all members of the organization and demonstrate that higher productivity is possible despite constraints. As per Theory A, an organization can showcase the performance of role models to improved targets and hence employee performance [21].

(7) Monitoring \& Guiding : The next component of Theory A is continuous monitoring of the employees performance and accelerating the productivity of the organization.
Such stage will automatically create responsibility and avoid redundancy. Monitoring process in theory A includes both self-monitoring and monitoring by superiors. Continuous monitoring and guiding process provides confidence among the employees and will keep the team together [16].

(8) Accountability : According to Theory A, accountability should be fixed to every member of the organization including the heads of the departments so that satisfaction and justice among the employees can be maintained in the organization. The final component of this organizational performance model is consistency in performance by the individuals. The accountability may be either positive or negative depending on organizational policy for achievers or losers respectively.

\section{THEORY OF ACCOUNTABILITY TO IMPROVE BANKING PRODUCTIVITY :}

Theory of Accountability can be applied to analyse and improve banking industry productivity by improving the employee performance at different levels. Irrespective of the digitalized work environment which have automated human resource processes and minimized human intervention in banking services, the performance management related challenges are continue to escalate. Performance management is also influencing the managers and employees at all levels banking industry to take a more active role in managing their performance and growth. Along with technology-enabled performance management, the organizations should focus on maximizing employee performance both individuals and teams. The perspective of Theory A for banking personnel point of view are listed in table 1 . 
Table 1 : Perspective of Theory A for Banking personnel

\begin{tabular}{|l|l|l|}
\hline $\begin{array}{l}\text { S. } \\
\text { No. }\end{array}$ & Stages of Theory A & Bank Personnel Point of view \\
\hline 1 & Planning & Business Development \\
\hline 2 & Target Setting & Examine the performance \\
\hline 3 & Developing Motivation & Career development \\
\hline 4 & Devising Work strategies & Practices and perfection \\
\hline 5 & Creating Responsibility & Delegation of authority \\
\hline 6 & Providing Role Model & Ideal bankers \\
\hline 7 & Monitoring and Guiding & Performance Evaluation \\
\hline 8 & Developing Accountability & Increases productivity and effectiveness \\
\hline
\end{tabular}

\section{(1) Planning:}

The banks need to be planned properly for their course of actions to provide quality services to the customers which are to be implemented in the organization. These plans should be properly communicated to every employee of different cadres. The day to day activities and transactions are properly planned according to customers point of view. Because ultimately banks should serve the customers in time as per their promise for business sustainability. Thus, planning is essential for every section of the bank to provide the best service to its stakeholders.

\section{(2) Target setting:}

Based on the planning, the managers should set the target for all employees in the bank. The target areas in a bank usually involve the number of deposits to be attracted, the amount of loans under different heads to be offered, the loan recovery, amount of loan recovery with time, attracting more new customers, retaining existing customers, improving security for transactions, offering a variety of financial services etc.

\section{(3) Motivation:}

The Theory A shows motivational factors which affectthe employees to work hard and to get benefited. It may be monetary or non-monetary factors which motivates the employees. Motivation also explains the benefits of focussed, dedicated, and committed work. Motivation is usually done by internal people like colleagues, Managers, or other role models in the bank. Through continuous motivation, every employee grabsthe opportunities for his/her individual growth along with the growth of the bank.

\section{(4) Work Strategies:}

Benchmarking plays a working strategy to compare the employee's performance in the banks. Every bank has a standard working procedure and the actual performance of the employees are measured against the set standards. Based on promoting suitable working strategies, the bank employees can focus and speed up their work and find innovative ways to completion. Theory A targets the working ability of employees through proper strategies to find optimum contribution.

\section{(5) Responsibility :}

Each employee should have a responsibility towards the completion of their work allotted to them. Sometimes it is a group responsibility along with the individuals. Theory A proposes that every employee should show higher priority to complete his work as he has a responsibility to fulfill the promises of his organization as its employee each work should give responsible to every employee and allocate them sufficient time and gap.

\section{(6) Role model :}

The manager or some of the employee of any bank should be a high achiever in terms of his own performance and contribution in providing innovative and satisfactory banking services to all stakeholders. Such role models are essential in every organization to prove that continuous improvements in banking services to create value addition is possible. The role model will be a motivator to many employees to reset their target. The showcase of a role model as an optimum performer is a major critical element in Theory A and will certainly boost the productivity of many employees.

(7) Monitoring \& Guiding:

Continuous monitoring on employee 
performance by his senior and timely guiding them for improving the performance is an essential hypothesis of Theory A. Managers have to adopt good evaluation process in checking the performance of the employees regularly and motivate and guide them periodically. The employees are encouraged to fulfil their target to improve the effectiveness and efficiency in fulfilling their responsibility. The expert in the specific field of banking may examine the works of their employees and suggests to improve and compete to their rivals.

\section{(8) Accountability:}

Accountability is the ability of the banks through their employees to give effective services, transparency, and conveyance. It shows the commitment of the banks towards their customers and improvement incorporated according to the customer suggestions. Accountability of employees may be positive or negative based on their performance. The employees who perform well and reach their target will be appreciated and the employees who fail to reach the target will be warned for better performance in order to serve the banking customers effectively.

\section{THEORY A FOR PUBLIC SECTOR BANKING IN INDIA :}

Public sector banks are under the control of Government of India. The power is fully concentrated at higher levels on many bureaucrats and unwilling to be shared so that the involvement of employees in the planning process becomes difficult. In such situation, no one has absolute power to take a decision. Even though every public sector bank has pre- determined standard set of conduct and job responsibilities are available, there is no encouragement from colleagues as well as from higher level managers. Many tasks of employees to be performed at customer contact point is routine and stereotype, posing no feeling of challenge. In such a scenario, employees will not any motivation and support to work uniquely through dedication and commitment by setting their working target as well as organizational target. This type of environment converts the employees to be a kind of lethargic and such attitude reflects in their services. This results in procrastination of innovation and hardly any application of work strategy to improve the quality at the workplace. Hence every employee avoids responsibility and passes the buck on other shoulders instead of showing selfresponsibility. As a result, there is no role model as an example to follow and continuous monitoring and guiding from higher level employees becomes absent. The control of employee unions is in the hand of wrong leaders leading to a continuous decrease in employee performance and productivity. Accountability is tumbling with time due to enhanced organizational politics and hardly few employees show commitment is work without any role model based inspiration. With all these characteristics of performance components, Theory A brings out the tales of poor performance of the public sector banks [22-23]. Table 2 depicts the scope of implementation of Theory A in public sector banks in India.

Table 2 : Scope of implementation of Theory A inpublic sector banks

\begin{tabular}{|l|l|l|}
\hline $\begin{array}{l}\text { S. } \\
\text { No. }\end{array}$ & Components of Theory A & Scope of Implementation \\
\hline 1 & Planning & Permanence of employees \\
\hline 2 & Target Setting & To tap the market \\
\hline 3 & Developing Motivation & Work motivation and satisfaction \\
\hline 4 & Devising Work strategies & Strategic thinking \\
\hline 5 & Creating Responsibility & Right approach with freedom \\
\hline 6 & Providing Role Model & Reward employees who step up \\
\hline 7 & Monitoring and Guiding & Examining and evaluating of banking services \\
\hline 8 & Developing Accountability & Becoming market leaders \\
\hline
\end{tabular}




\section{THEORY A FOR PRIVATE SECTOR BANKING IN INDIA :}

Private banks offer huge potential for creativity and contribute to all sorts of innovations in banking services by their employees. The bureaucratic setup does not affect and interfere with the planning process of the employees for performance. The employees can plan and execute better services to satisfy the customers through their own freedom and scope of creativity. Due to available proactive motivation from their superiors, the employees can develop their work strategies democratically. As a result, while executing their work, they own higher responsibility and serves more voluntarily. In private sector banks, the leader who influences the employees through his/her superior performance will become a role model and further accountability can be improved through setting working standards. However, some of the private banks are characterized by lower power delegation at lower levels leading to planning becomes less important than the implementation of standard procedures of customer services. In private banking systems like ICICI bank, HDFC bank etc. the management style is clearly authoritarian and employees are bound to execute the directions to deliver the quality services. In private banks, usually the superior is the role model to be copied and strong control is exercised in monitoring the quality of services. Finally, the accountability in private banks is also strictly implemented through promotion and incentives for positive performers for their innovations and commitments. On the other hand, the low performers and poor decision makers are discouraged to continue in their positions through tough valuations and discharging strategies [24]. Table 3 depicts the scope of implementation of Theory A in private sector banks in India.

Table 3 : Scope of implementation of Theory A inprivate sector banks

\begin{tabular}{|l|l|l|}
\hline $\begin{array}{l}\text { S. } \\
\text { No. }\end{array}$ & Components of Theory A & Scope of Implementation \\
\hline 1 & Planning & Optimum usage of manpower \\
\hline 2 & Target Setting & Expansion of share-in the market \\
\hline 3 & Developing Motivation & Incentives and promotion \\
\hline 4 & Devising Work strategies & Achieving objectives \& strategic implementation \\
\hline 5 & Creating Responsibility & Encourage a sense of ownership \\
\hline 6 & Providing Role Model & $\begin{array}{l}\text { Expert excellence and opportunity to be a role } \\
\text { model }\end{array}$ \\
\hline 7 & Monitoring and Guiding & Measuring the performance and results \\
\hline 8 & Developing Accountability & $\begin{array}{l}\text { Opportunity to develop new model and grant } \\
\text { benefit }\end{array}$ \\
\hline
\end{tabular}

improve the quality of services and to make

\section{THEORY A BASED SUGGESTIONS :}

(1) Planning in banks at every employee level is an essential component to implement the objective of providing value based quick services to the customers. The banking organizations should develop a culture to create the best service document by means of systematic planning by every employee so that the employee's involvement in providing value added services will enhance. Banks can train their employees in the planning process to them focused on the organizational goals.

(2) Target setting is another essential component for the employees with the guidance from their seniors or superiors. The target areas in a bank may be on the number of deposits to be attracted, the amount of loans under different heads to be offered, the loan recovery, amount of loan recovery with time, attracting more new customers, retaining existing customers, improving security for transactions, offering a variety of financial services etc. These targets should be made clear to all employees at 
different cadre to improve the efficiency and effectiveness of their services. During target setting, equal opportunities should be given for all cadres of employees in the organizations to maintain homogeneous enhancement of performance. The credit management department should take care about loan issues and recovery systems.

(3) Motivation is another essential component to enhance organizational performance. Banks which incorporate various motivational strategies can align the employees focus on quality services through dedication and commitment. Motivation can be monetary or non-monetary to boost the morale of the employees. Motivation of colleagues and subordinates is the responsibility of the bank employee at every level. The person who motivates the employees may be an internal achiever or external achiever called role model in the bank. Through continuous motivation, every employee grabs the opportunities for his/her individual growth along with the growth of the bank.

(4) Banks should see that every employee has prepared and maintaining their respective work strategy to provide quality service to their customers. Benchmarking the work strategies to improve the employee's performance is the essential part in this regard. Every bank should maintain a standard working performance and the actual performance of the employees are measured against the set standards. Based on promoting suitable working strategies, the banks should maintain optimum contribution from every employee. The working strategies should focus their roots in the basic elements like effective Customer Relationship Management, Total Quality Management, and Talent Management in order to extract best performance among employees.

(5) When every employee is properly educated by setting their responsibility towards organizational growth by optimising their individual contribution along with teamwork. Giving responsibility makes employees matured and stimulates them to contribute by taking any risk. When the employee has responsibility towards fulfilling the promises offered by the bank towards its customers, his commitment will be at optimum level and hence shows high priority to achieve it.

(6) In order to give confidence in the work to achieve the goal, every employee should realize that his target is achievable. Banks should appoint some high performers even at high cost to show that every employee can set high and achievable target which is already proven by such role models and hence give confidence that high targets are achievable. The role model is essential in many banks to motivateand reset their target to further higher level. The showcase of a role model as an optimum performer is a major critical element in Theory A and will certainly boost the productivity of many employees.

(7) The performance of the banking employees towards fulfilling their responsibilities should be monitored by the superiors continuously by adopting a good evaluation process through customer feedback. They should be periodically motivated and guided in order to maintain effective and efficient services to the customers. The designated experts in the specific field of banking should examine the works of their employees and suggests to improve and compete to the services provided with their rivals.

(8) Every bank should adopt the accountability component very strictly. Every bank should show its accountability through the quality of services it provides to its customers by its employees. Apart from the accountability of the bank as a whole towards providing secured services in time by adopting the optimum technology, bank has to implement a policy of maintaining accountability of its employees in providing quality services irrespective of the cadre. The best performers should be rewarded and the poor performers should be penalised appropriately. The banks should develop a mechanism to identify and implement the accountability of the employees in a time bound manner. This will lead to improved customer service and hence name and fame to the bank.

The suggestions based on the outcomes of this research shall help and support the banks to identify the factors according to Theory A that influence the employee performance in the 
banking organizations. It creates a healthy competition between public banks and private banks. This will further help to the human resource department of every bank to increase the productivity of their employees.

\section{CONCLUSION :}

Theory A focuses on the innate human urge for creativity based on the internal and external motivation in an organizational environment. This will boost both individual and organizational performance. This model can be effectively used in the banking industry both for the public sector and the private sector. Since the success in banking service business depends on how employees interact and behave with the customers to speed up the requested service, Theory A gives optimum solutions to improve employees performance. Based on the qualitative discussions, it shows that all components of Theory A can be successfully applied to the banking sector to improve the productivity through enhanced employee performance which will certainly reap the longterm profits of the organization. This is due to the fact that the human productivity in banking sector depends mainly on how efficiently the workers are managed. Along with organizational objectives, each individual employee objective if aligned with organizational objectives leads to setting up a right target for individual employees. Motivation then brings in responsibility to transform into performance. Application of Theory A in banking sector decreases the rigidity and power structure of the organization and focus on changing the outlook of the modern workforce, modifying the perspectives of the employer, improving the management style, and a test for newer forms of governance.

\section{REFERENCES:}

[1] Varambally, K. V. M. \& Aithal, P. S. (2009). Technological Management and Mobile Business Services in India - A Futuristic Approach. Proceedings on MIDISA SAARC Conference on Change and Continuity : Management Prospects and Challenges, RIM, Thimphu, Bhutan, 121139.
[2] Aithal, P. S., \& Varambally, K. V. M. (2009). Mobile Business Technology and Business Proliferation of Banks - A futuristic Approach. Amity Business Review - an Indian Journal, 10(1), 9-25.

[3] Aithal, P. S. (2015). Factors Affecting Banker's Perspective on Mobile Banking. International Journal of Management, IT and Engineering (IJMIE), 5(7), 28-38. DOI : http://doi.org/10.5281/zenodo.268816.

[4] Aithal, P. S., \& Shubhrajyotsna Aithal, (2015). Ideal Technology Concept \& its Realization Opportunity using Nanotechnology.International Journal of Application or Innovation in Engineering \& Management (IJAIEM), 4(2), 153 - 164. DOI: http://doi.org/10.5281/zenodo.61591.

[5] Aithal, P. S. (2016). Ideal Banking Concept and Characteristics. International Research Journal ofManagement, IT and Social Sciences (IRJMIS), 3(11), 46-55. DOI : http://doi.org/10.21744/irjmis.v3i11.311.

[6] Aithal, P. S. (2016). Realization of Ideal Banking Concept using Ubiquitous Banking. International Journal of Scientific Research and Modern Education (IJSRME), 1(2), 119-135. DOI: http://doi.org/10.5281/ZENODO.164703.

[7] Aithal, P. S. (2016). A Comparison of Ideal Banking Model with Mobile Banking System.International Journal of Current Research and Modern Education (IJCRME), 1(2), 206-224.DOI: http://doi.org/10.5281/ZENODO.198708.

[8] Aithal, P. S. (2016). Review on Various Ideal System Models Used to Improve the Characteristics of Practical Systems. International Journal of Applied and Advanced Scientific Research, 1(1), 47-56. DOI http://doi.org/10.5281/zenodo.159749.

[9] Aithal, P. S. (2016). A Review on Advanced Security Solutions in Online Banking Models. International Journal of Scientific Research and Modern Education 
(IJSRME), 1(1), 421-429. DOI : http://doi.org/10.5281/zenodo.160971.

[10] Aithal P. S. and Varambally K. V. M. (2006). Security Issues in Online Financial Transactions with Special Reference to Banking Industry. In Quality in Service Sector and Managerial Challenges - Allied Publisher Pvt. Ltd. 2006, ISBN: 81-7764992-2, pp. 103- 114.

[11] Banker, R. D., Chang, H., \& Lee, S. Y. (2010). Differential impact of Korean banking system reforms on bank productivity. Journal of Banking \& Finance, 34(7), 1450-1460.

[12] Colwell, R. J., \& Davis, E. P. (1992). Output and productivity in banking. The Scandinavian Journal of Economics, S111S129.

[13] Kumbhakar, S. C., \& Sarkar, S. (2003). Deregulation, ownership, and productivity growth in the banking industry: evidence from India. Journal of Money, Credit and Banking, 403-424.

[14] Sherman, H. D., \& Ladino, G. (1995). Managing bank productivity using data envelopment analysis (DEA). Interfaces, 25(2), 60-73.

[15] Aithal, P. S., \& Suresh Kumar, P. M. (2016). Theory A for Optimizing Human Productivity. IRA-International Journal of Management \& Social Sciences, 4(3), 526535.

DOI

http://doi.org/10.21013/jmss.v4.n3.p2.

[16] Aithal, P. S. and Suresh Kumar, P. M. (2016). Organizational Behaviour in $21^{\text {st }}$ Century - Theory A for Managing People for Performance. IOSR Journal of Business and Management (IOSR-JBM), 18(7), 126134. DOI: http://doi.org/10.9790/487X180704126134.

[17] Aithal, P. S.\& Suresh Kumar, P. M. (2016). Comparative Analysis of Theory X, Theory $\mathrm{Y}$, Theory Z, and Theory A for Managing People and Performance. International Journal of Scientific Research and Modern Education (IJSRME), 1(1), 803-812. DOI: http://doi.org/10.5281/zenodo.154600.

[18] Aithal, P. S. \& Suresh Kumar, P. M. (2016). CCE Approach through ABCD Analysis of 'Theory A' on Organizational Performance. International Journal of Current Research and Modern Education (IJCRME), 1(2), 169-185. DOI: http://doi.org/10.5281/zenodo.164704.

[19] Aithal, P. S. \& Suresh Kumar, P. M. (2016). Application of Theory A on ABC Model to enhance Organizational Research Productivity in Higher Education. International Journal of Advanced Trends in Engineering and Technology (IJATET), 1(1), 142-150. DOI http://doi.org/10.5281/zenodo.240646.

[20] Aithal, P. S., Suresh Kumar P. M. (2017). Integrating Theory $\mathrm{A}$ and Six Thinking Hats for Improved Organizational Performance. International Journal of Applied Engineering and Management Letters (IJAEML), 1(2), 66-77. DOI: http://doi.org/10.5281/zenodo.1045417.

[21] Aithal, P. S. (2018). Effect of Role Models - A Critical Study on the Recent Research Contribution of Vice-chancellors of Selected Private Universities in India. International Journal of Management, Technology, and Social Sciences (IJMTS), 3(1), 118-139. DOI http://doi.org/10.5281/zenodo.1257729.

[22] Aithal, P. S. \& Varambally, K. V. M. (2015). Customer Perspective on Online Mobile Banking in India - An Empirical Study. International Journal of Management, IT and Engineering (IJMIE), 5(7), 77-97. DOI http://doi.org/10.5281/zenodo.268818.

[23]Shouvik Sanyal, Mohammed Wamique Hisam, (2018). Impact of Training and Development on the Performance of Employees - A Comparative Study on Select Banks in Sultanate of Oman. International Journal of Scientific Research and Management, 6(03), 191-198. DOI: https://doi.org/10.18535/ijsrm/v6i3.e $\mathrm{m} 02$. 
[24] Jensen, S. M., Luthans, K. W., Lebsack, S. A., \& Lebsack, R. R. (2007). Optimism and employee performance in the banking industry. Journal of Applied Management and Entrepreneurship, 12(3), 57. 